CASSOWARY volume 5 (1) Januari 2022: 1 - 10

ISSN : 2614-8900

E-ISSN : 2622-6545

Program Pascasarjana Universitas Papua, https://pasca.unipa.ac.id/

\title{
Pengetahuan lokal berbasis masyarakat adat untuk pengelolaan tanaman masohi: pembelajaran dari Distrik Teluk Patipi Kabupaten Fak-Fak
}

\author{
Arnoldus Tuturop ${ }^{1}$, Hendri ${ }^{1}$, Julis D Nugroho ${ }^{1}$ \\ ${ }^{1}$ Program Studi S2 Kehutanan, Program Pascasarjana, Universitas Papua \\ Jalan Gunung Salju, Amban, Manokwari, Kodepos 98314, Papua Barat, Indonesia \\ *Email: h.hendri@unipa.ac.id
}

Disubmit: 13 Agustus 2021, direvisi: 30 Desember 2021, diterima: 10 Januari 2022

Doi: https://doi.org/10.30862/casssowary.cs.v5.i1.113

\begin{abstract}
Masohi bark is a primadonna product other than in Fak-Fak Regency, therefore it is necessary to study the preservation and development of masohi plants. Masohi has been developed based on local knowledge based on indigenous peoples. Survey method by exploring key figures related to land history, cultivation techniques, harvesting, and processing masohi bark. Furthermore, these data were analyzed using a Likert scale and showed that the role of indigenous peoples was still very high. The results showed that community seed gardens helped a lot in providing quality seeds with maintenance, prioritizing organic fertilizers, some harvesting of masohi bark was still being cut down, and problems with drying when wet conditions. In addition, it was also found that their management is still not based on technology and adaptation to climate change. Several strategic proposals are needed for further development for the parties so that sustainable management can still be sustainable in terms of quantity and quality.
\end{abstract}

Keywords: local knowledge, indigenous peoples, masohi

PENDAHULUAN

Massoi (Cryptocarya massoia (Oken) Kosterm) diklasifikasikan sebagai keluarga (family) Lauracea. Masohi secara geografis tersebar di daerah tropis, New Guinea, Queensland dan Australia (Westhpal \& Jansen 1989). Di wilayah Papua, jenis ini ditemukan di wilayah Nabire, Sarmi, Yayapura dan Merauke, sedangkan di Papua Barat, masohi ditemukan di wilayah Kabupaten Teluk Wondama, Kaimana, Teluk Bintuni, Manokwari Selatan dan Fakfak (Remetwa, 2000; Yeny dan Nuroniah, 2018; Hutapea dkk, 2020). Populasi terbanyak dijumpai di wilayah Kabupaten Teluk Wondama dan FakFak. Berdasarkan pengetahuan lokal masyarakat adat, ekstrak kulit kayu masohi dapat digunakan sebagai minyak gosok untuk pegal dan sakit kepala. Disamping itu juga digunakan untuk obat tradisional sakit demam, diare dan pemulihan tubuh setelah melahirkan (Westhpal \& Jansen 1989). Peneliti lainnya (Erari, 2005; Pasapan, 2005; Putra, 2003) juga mengungkapkan bahwa kulit kyu masohi digunakan untuk obat tradisional terkait penyakit paruparu seperti tuberculosis (TBC), 
pneumonia, bronchitis dan juga utnuk mengobati gigitan ular.

Ekstrak kulit kayu masohi bernilai ekonomi tinggi yang umumnya digunakan sebagai bahan baku aromatik untuk makanan, obat-obatan, parfum, aromaterapi dan minuman herbal. Permintaan minyak masohi yang termasuk dalam hasil hutan bukan kayu (HHBK) tergolong tinggi untuk pasar dalam negeri dan luar negeri (Sudarmalik dkk, 2006; Baharuddin dan Taskirawati, 2009; Hastanti dkk, 2016). Harga kulit kayu masohi di pasaran online berkisar Rp 150.000,00 - 200.000,00/ kg dan lokasi pengepul daerah terutama di FakFak berkisar Rp 40.000,00 - 60.000,00/kg. Sedangkan harga minyak masohi dihargai rata-rata sebesar $\mathrm{Rp}$ 3.250.000,00/liter dengan komposisi jika mengandung laktone $50 \%$ (harga $\mathrm{Rp}$ 2.500.000,00 - 2.800.000,00) dan laktone $70 \%$ (harga mencapai Rp 4.500.000,00) (BP2I, 2014).

Namun aktivitas pemanenan kulit kayu masohi masih menggunakan sistem tebang di wilayah Papua yang sudah berlangsung sejak abad ke 17 (Westhpal \& Jansen 1989) dan puncaknya terjadi pada tahun 1990an. Ketersediaan masohi di hutan alam mengalami pengurangan
(Nugroho et al., 2019) dan terindikasi bahwa penebangan masohi telah dilakukan pada kelas diameter rendah.

Upaya konservasi ex-situ menjadi prioritas untuk mengatasi permasalahan terkait keberlanjutan tanaman masohi di Papua. Penelitian ini dilakukan untuk menjawab permasalahan tersebut melalui pembelajaran pengembangan masohi oleh masyarakat adat dalam kerangka hutan desa berdasarkan pengetahuan lokal di Distrik Teluk Patipi Kabupaten FakFak yang sudah dimulai sejak tahun 1980.

\section{MATERI DAN METODE}

\section{Lokasi Penelitian}

Penelitian dilakukan di Distrik Teluk Patipi Kabupaten Fakfak Provinsi Papua Barat yang secara geografis terletak diantara LS $02^{\circ} 33^{\prime} 25^{\prime \prime}$ - $02^{\circ} 55^{\prime} 35^{\prime \prime}$ dan BT $132^{\circ} 16^{\prime} 54^{\prime \prime}$.

Survei lapangan dilakukan pada lokasi 7 kampung yang terletak di pesisir pantai yaitu Sum, Puar, Us, Adora, Muhri, Degen, Tetar, (Gambar 1) dengan kehidupan masyarakat yang terkait erat dengan penanaman tanaman masohi berdasarkan pengetahuan lokal.

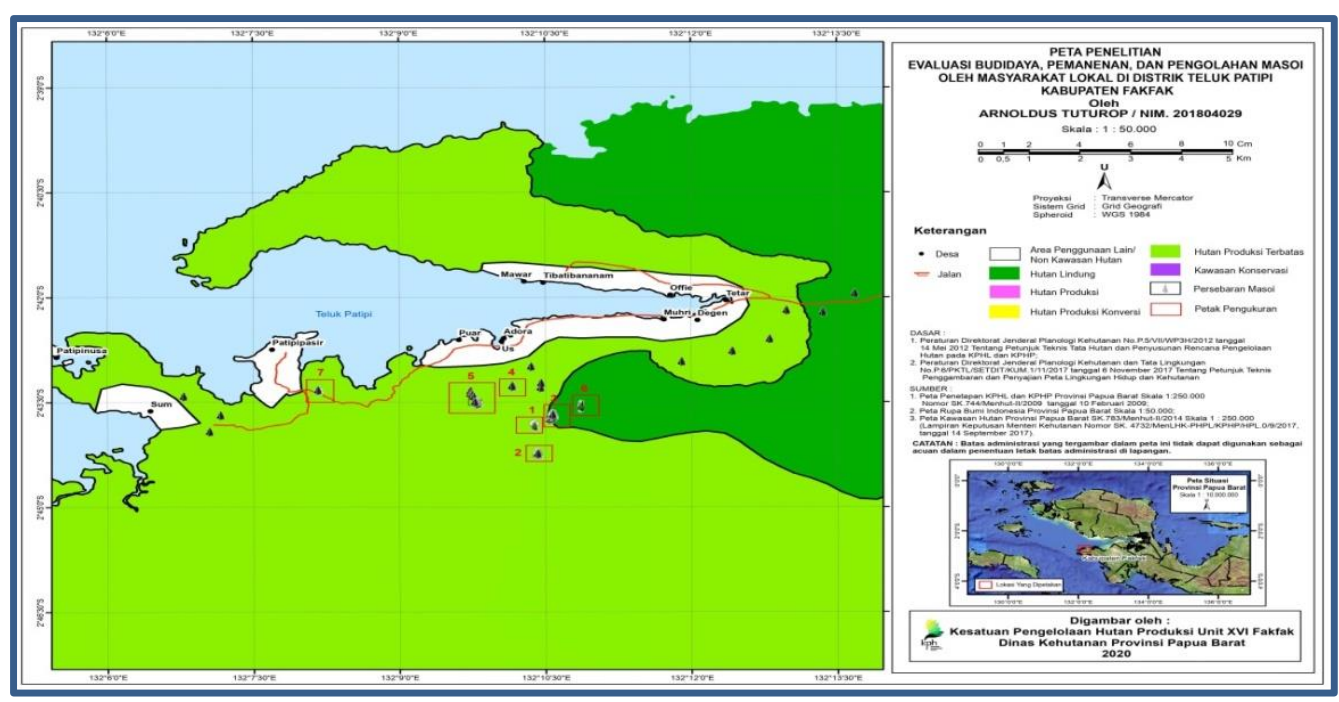

Gambar 1. Lokasi penelitian di Distril Teluk Patipi 


\section{Responden dan Pengumpulan Data}

Metode yang digunakan dalam penentuan sampel dari populasi untuk penelitian sosial dengan memperhatikan waktu dan biaya adalah menggunakan salah satu syarat minimum berjumlah 30 responden (Cohen, et al., 2007).

Responden kunci tersebar di 7 kampung yang terdiri dari 9 marga keluarga yaitu Tuturop, Kabes, Hindom, Koroute, Bahamba, Sagas, Kaninggai, Iha dan Muri.

Pengumpulan data yang diperlukan dalam penelitian ini, yaitu:

1. Sejarah lahan dan tanaman

2. Teknik budidaya yang dimulai dari pembibitan, penanaman, dan pemeliharaan.

3. Pemanenan

4. Praktek pengeringan
Data di analisis dengan menggunakan skala Likert. Bobot atau skor yang diberikan untuk pernyataan ini misalnya Sangat Setuju $(\mathrm{SS})=5$, Setuju $(\mathrm{S})=4$, Kurang Setuju $(\mathrm{KS})=3$, Tidak Setuju $(\mathrm{TS})=2$, dan Sangat Tidak Setuju (STS) $=1$. Interval Penilaian: Indeks $0 \%-$ 19,99\% (Sangat Tidak Setuju), Indeks $20 \%$ - 39,99\% (Tidak Setuju), Indeks 40\% - 59,99\% (Kurang Setuju), Indeks $60 \%-79,99 \%$ (Setuju), Indeks 80\% $100 \%$ (Sangat Setuju).

\section{HASIL DAN PEMBAHASAN}

\section{Sejarah Lahan dan Tanaman}

Sejarah lahan dan tanaman dilihat dari tahun tanam, luasan, marga dan posisi kampung yang dapat dilihat pada Tabel 1.

Tabel 1. Sejarah lahan dan tanaman masohi

\begin{tabular}{clccll}
\hline No & Kampung & $\begin{array}{c}\text { Tahun } \\
\text { Tanam }\end{array}$ & $\begin{array}{c}\text { Luasan } \\
(\text { Ha) }\end{array}$ & \multicolumn{1}{c}{ Keluarga } & Hak Waris \\
\hline 1 & Us & 1980 & 1 & Antonius Tuturop & Arnoldus Tuturop \\
2 & Puar & 1980 & 1 & Felix Bahamba & - \\
3 & Muhri & 1980 & 1 & Abraham Kabes & Zeth Kabes \\
4 & Tetar & 1980 & 1 & Yusuf Kabes & Anderson Kabes \\
5 & Degen & 1980 & 1 & Yeheskel Kabes & Lukas Kabes \\
6 & Degen & 2002 & 1 & Yeheskel Kabes & Lukas Kabes \\
7 & Tetar & 2003 & 1 & Maxi Hindom & Yosafat Hindom \\
8 & Puar & 2007 & 2 & Adrian Kaninggai & - \\
9 & Muhri & 2008 & 1 & Melkion Iha & - \\
10 & Puar & 2009 & 1 & Jacob Karoute & - \\
11 & Adora & 2009 & 1 & Lukas Muri & - \\
12 & Us & 2010 & 2 & Antonius Tuturop & Arnoldus Tuturop \\
13 & Puar & 2010 & 1 & Melkianus Bahamba & Andreas Bahamba \\
14 & Puar & 2010 & 1 & Yafat Sagas & Riko Sagas \\
15 & Muhri & 2010 & 1 & Oktivianus Kabes & Yudas Kabes \\
16 & Muhri & 2010 & 1 & Vincent Hindom & Fansiskus Hindom \\
17 & Degen & 2010 & 1 & Jullius Hindom & Joni Hindom \\
18 & Tetar & 2010 & 1 & Tonce Kabes & Sefnath Kabes \\
19 & Sum & 2015 & 1 & Jeremias Tuturop & - \\
& Total & & $\mathbf{2 1}$ & & \\
\hline
\end{tabular}


Sejarah lahan ini diawalin dengan pembukaan lahan yang berasal dari hutan alam yang setiap marga memiliki kemampuan seluas $1-2$ ha. Sehingga total penanaman masohi di Distrik Patipi ini mencapai \pm 20 ha. Penanaman diawalin pada tahun 1980 oleh keluarga Tuturop, Bahamba dan Kabes pada Kampung Us, Puar, Muhri, Degen dan Tetar yang selanjutnya menjadi kebun benih. Kemudian, pada tahun 2000 ke atas baru dikembangkan di 2 kampung lainnya, yaitu Sum dan Adora dan juga 6 marga lainnya yang baru terlibat. Untuk selanjutnya pengelolaan lahan masohi tersebut diberikan hak miliknya kepada Anak Pertama selaku hak waris (Tabel 1, Gambar 2).

Pembukaan lahan yang dilakukan oleh masyarakat adat dilakukan dengan cara rintis dengan mambabat rumputan dan memotong kayu ringan seperti macaranga (macaranga spp.), ficus (ficus sp.) dan pulai (Alstonia scholaris).

Sedangkan kayu komersial seperti merbau (Intsia bijuga), matoa (Pometia pinnata), anakan pala (Myristica fragrans), anakan masohi (Cryptocarya massoia (Oken) Kosterm), dan buahbuahan komsersil seperti durian (Durio zibethinus), langsat (Lansium domesticum), alpukat (Persea americana), dan sukun (Artocarpus altilis) tetap dipertahankan.

Hasil rintisan biomassa yang telah dipotong kemudian dikumpulkan pada suatu tempat dan selanjutnya dibakar. Hasil pembakaran ini selanjutnya digunakan sebagai pupuk organik untuk tanaman pertanian dan anakan masohi.

Proses pembukaan lahan kebun pertanian dan masohi menganut sistem perladangan berpindah (Gambar 2) dengan menerapkan pola agroforestri tradisional yang dikenal dengan istilah agrisilvicultural yang memadukan tanaman kehutanan (seperti merbau dan matoa) dan Multi Purpose Tree Species
(MPTS) (seperti durian, langsat, alpukat, sukun, pisang) dengan tanaman pertanian (seperti kacang-kacangan, umbiumbian, keladi, dan sayur gedi).

Proses perladangan berpindah tersebut bisa kembali lagi pada lahan semula jika tanaman masohi sebagai tanaman utamanya tersebut sudah dipanen dengan diameter $15 \mathrm{~cm}$ dengan asusmsi pertumbuhan sebesar $1 \mathrm{~cm}$ per tahun maka diperkirakan kurun waktu rotasi selama 15 tahun.

Riap masohi pada umur 5 tahun sudah tidak memungkinkan tanaman pertanian untuk tumbuh karena luasan tajuk sudah cukup rimbun dan menutupi lahan dibawahnya. Sehingga masyarakat melakukan pembukaan lahan baru kembali untuk proses pemenuhan tanaman pangan sebagai ketahanan pangan.

Reponden pada umumnya petani yang berusia produktif ( $<50$ tahun). Hal ini menunjukkan bahwa regenerasi pengetahuan lokal dari Tetua Adat ke generasi muda sudah berjalan dengan baik seiring dengan tingkat pengetahuan dan pendidikan (Gambar 2).

Kepemilikan lahan masohi ini merupakan hak komunal dari marga dan diberikan kepada keluarga dengan marga yang sama untuk kelola masohi di tanah hutan adat mereka (Gambar 2).

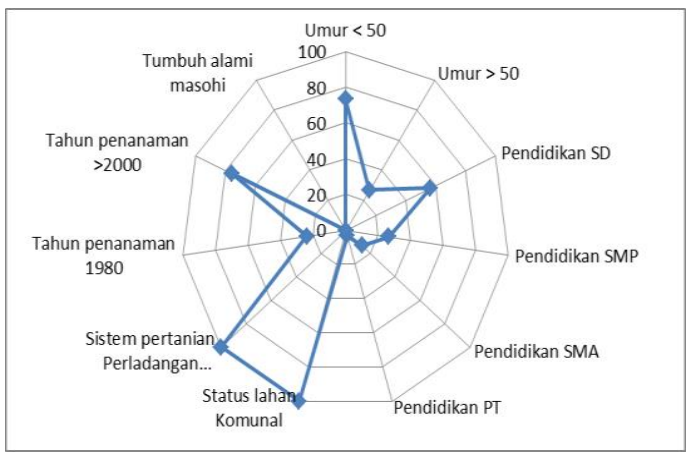

Gambar 2. Persentase sejarah lahan dan tanaman

Teknik Silvikultur 


\section{Pembibitan dan Penanaman}

Pembibitan masohi dilakukan dengan menggunakan propagul berupa biji $(50 \%)$ ataupun cabutan masohi $(50 \%)$. Benih berupa biji masohi dikumpulkan dari bawah tegakan masohi yang telah jatuh dan disemaikan pada bedengan semai berupa pondok semai yang didirikan di kebun atau di sekitar pekarangan rumah. Hal yang sama juga dilakukan pada bibit asal cabutan semai masohi dari kebun bibit (5 ha) yang ditanam pada bedengan semai di pondok semai (Gambar 3A). Bibit masohi yang telah memiliki jumlah daun 4-6 lembar menunjukkan bahwa bibit tersebut telah siap untuk dipindahkan ke polibag (Gambar 3B). Dalam pemeliharaan bibit di persemaian petani tidak menggunakan pupuk maupun insektisida. Bibit masohi berada di persemaian sekitar 6 - 8 bulan. Pembukaan kebun baru untuk menanam tanaman pertanian (semusim) dilakukan secara berpindah-pindah. Kebun tua akan ditinggalkan bersama dengan tegakan masohi yang telah tumbuh dengan baik dan petani akan mencari lokasi baru untuk membuka kebun barunya. Setiap melakukan pembukaan kebun baru selain tanaman semusim, petani juga menanam masohi. Bibit masohi yang sudah ditanam di kebun diberi tanda berupa patok kayu kemudian diperakarannya diberi tumpukan kayu lapuk (Gambar 3 C-D).

Secara keseluruhan persentase tahapan pembibitan berdsasarkan pengetahuan masyarakat lokal disajikan pada Gambar 4.
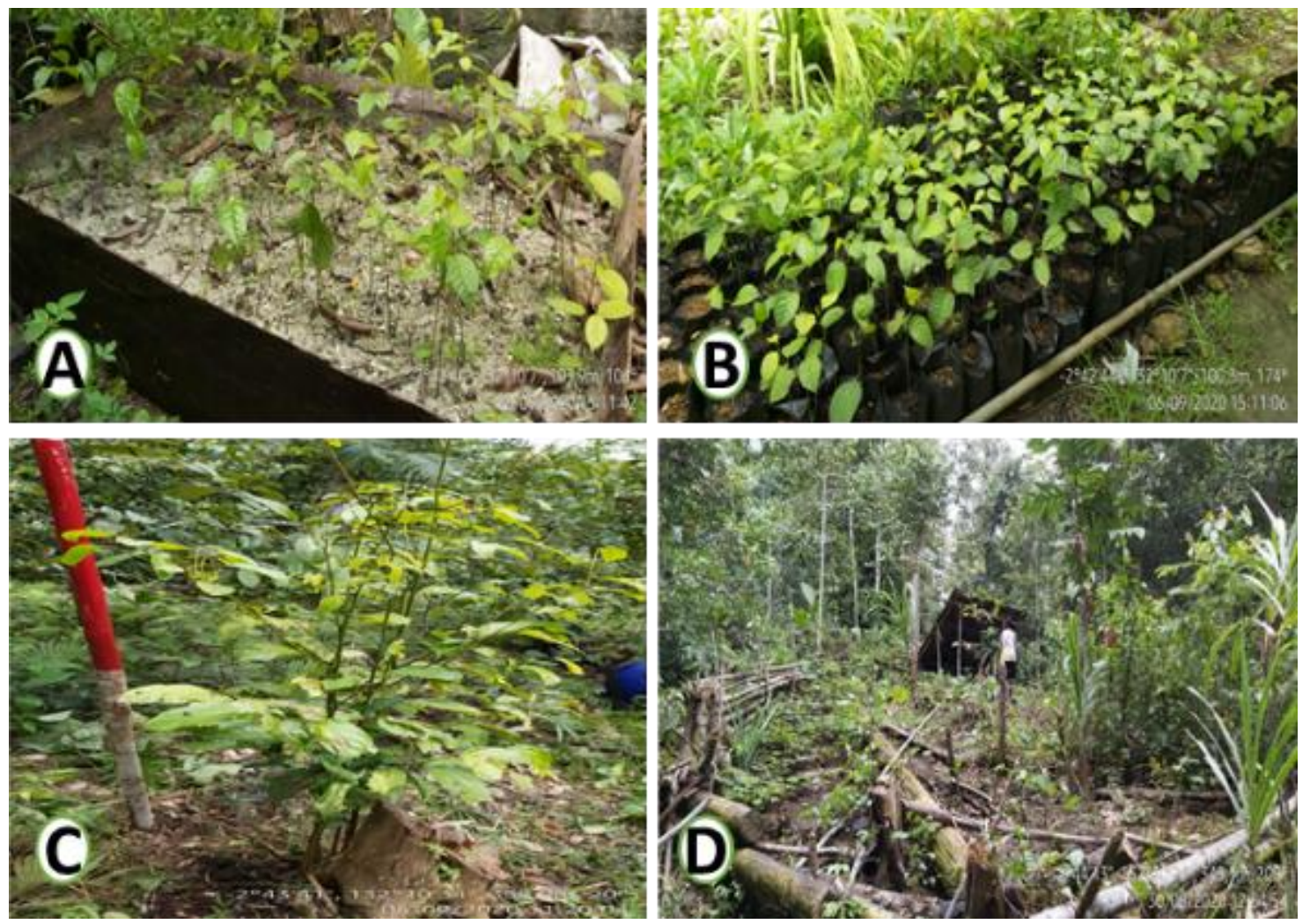

Gambar 3. Pengetahuan pembibitan masohi oleh masyarakat lokal. A. Semai masohi di bedeng perkecambahan; B. Semai hasil perkecambahan dipindahkan ke polybag; C-D. Penanaman masohi bercampur dengan tanaman lain (agroforestri) dengan pembeda diberikan tanda ajir kayu. 


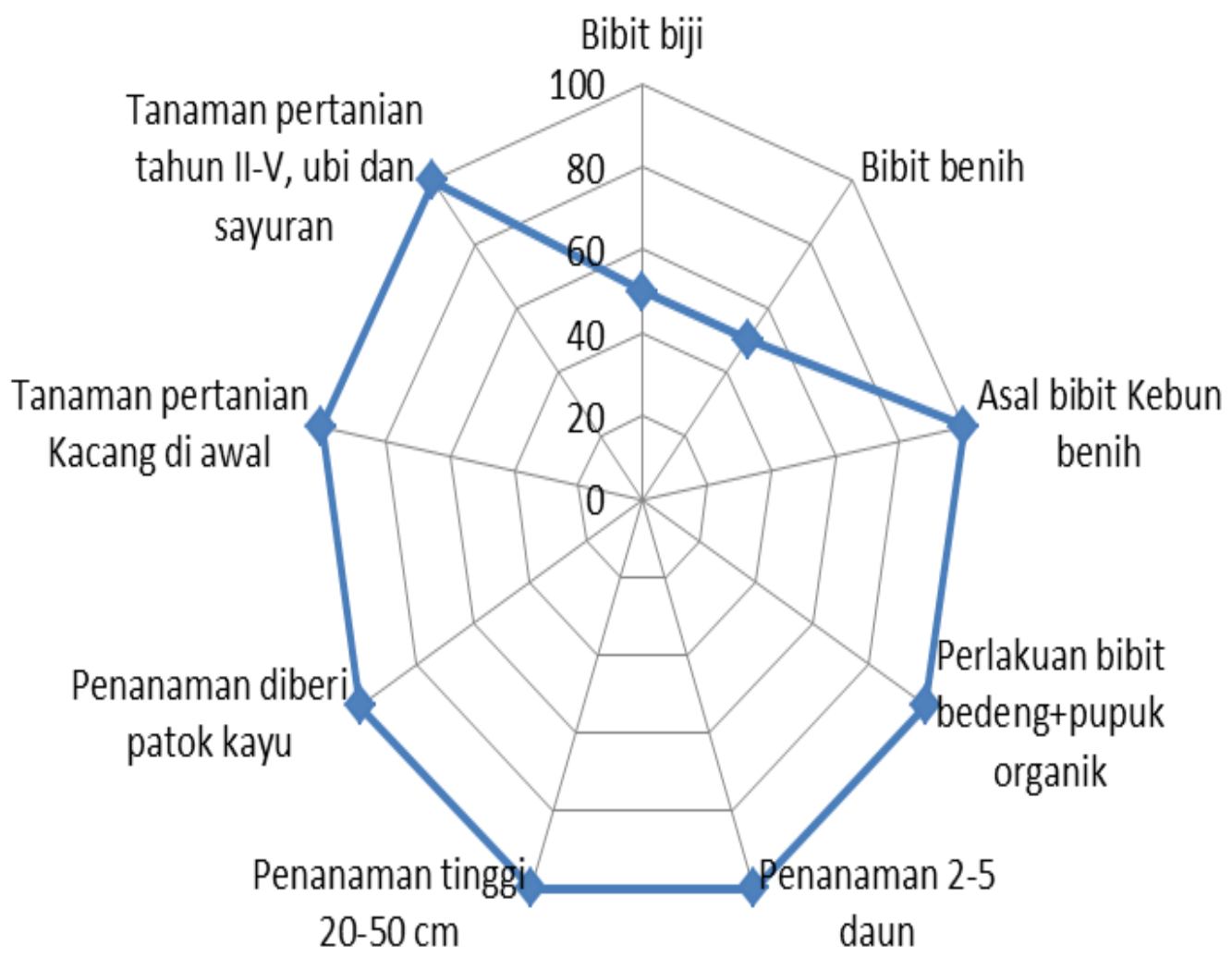

Gambar 4. Persentase pembibitan

Gambar tersebut menunjukkan bahwa peran kebun benih masyarakat sangat strategis dibutuhkan dalam upaya peningkatan persentase pembibitan yang berasal dari cabutan benih unggulan dan tidak berasal dari biji yang disemaikan.

Penanaman masohi di lapangan dengan memperhatikan kondisi benih yang sudah tumbuh $2-5$ daun dengan ketinggian mencapai $20-50 \mathrm{~cm}$. Tanaman masohi dicampur dengan tanaman kacang pada awal tahun agar kondisi tanah mendapatkan tambahan unsur hara $\mathrm{N}$ dari bintik akar kacang. Selanjutnya, pada tahun kedua sampai kelima, tanaman pertanian yang digunakan adalah umbi-umbian, keladi dan sayuran.

\section{Pemeliharaan}

Pemeliharaan tanaman masohi di kebun secara khusus seperti penyiangan rumput dilakukan oleh keluarga petani. Pemeliharaan lainnya dengan melakukan pemupukan yang bersamaan tanaman pala serta tanaman buah-buahan dan kehutanan dengan menggunakan pupuk organik yang berasal dari sisa kayu lapuk dan dedaun yang diletakkan di atas perakaran. Sedangkan penyiraman masih mengandalkan air hujan dan mengalami permasalahan jika dalam kemarau panjang atau kebanjiran dalam kondisi ekstrim akibat perubahan iklim. Oleh karena itu, diupayakan untuk membuat biopori untuk mengatasi permasalaham ekstrim tersebut pada beberapa titik di kebun (Ulfah dkk, 2016; Dahliati dkk,2019).

Pemeliharaan tanaman masohi tingkat pancang, tiang dan pohon berdasarkan pengetahuan local yang dilakukan adalah praktek mematikan pohon dengan cara mengupas bagian floem tanaman secara melingkar. Praktek seperti demikian ditujukan untuk menghilangkan pohon yang kurang bermanfaat dan menjadi penghalang pertumbuhan masohi seperti jenis-jenis 
tumbuhan yang tumbuh cepat (Macaranga spp. dan jenis pionir lainnya).

Pohon-pohon penghalang tersebut tidak keseluruhannya dimatikan. Beberapa pohon besar yang dianggap sebagai pohon pelindung biasanya tetap dipertahankan, yang ditujukan untuk menjaga keseimbangan ekosistem alam.

Praktek mematikan pohon tersebut dilakukan dengan cara meneres (menguliti) kulit batang untuk merusak jaringan pengangkutan (phloem) sehingga lamakelamaan pohon akan mati mengering karena perakaran tidak mendapatkan suplai energi hasil fotosintesis (Gambar 5).
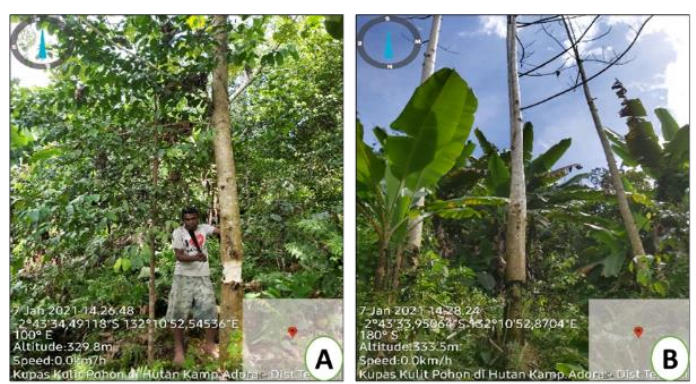

Gambar 5. Menghilangkan penghalang pertumbuhan masohi, A. Cara kupas kulit/batang pohon (teres), dan B. Hasil teres pohon penghalang.

Adapun secara keseluruhan proses pemeliharaan ini dapat dilihat pada Gambar 6.

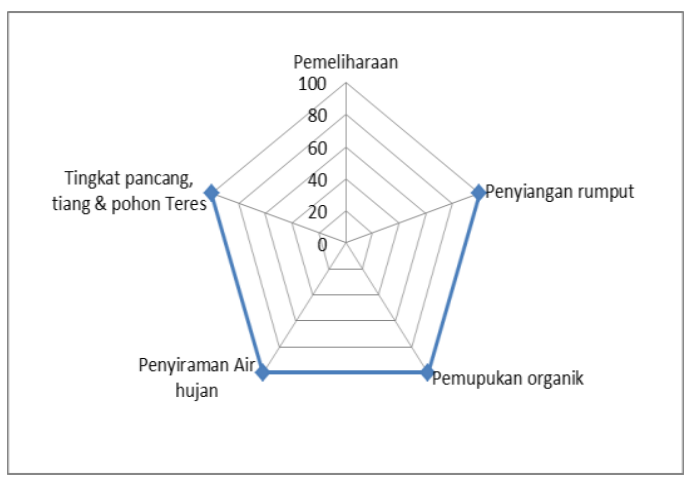

Gambar 6. Persentase pemeliharaan

\section{Pemanenan}

Masohi memiliki kaitan erat dengan kehidupan sosial budaya masyarakat lokal di Distrik Teluk Patipi dan merupakan berkat Tuhan yang diberikan kepada mereka yang diwariskan dari nenek moyang mereka dan masih terjaga melalui Tetua Adat.

Masyarakat percaya bahwa generasi saat ini merupakan generasi penghubung kehidupan masa lampau. Oleh sebab itu, warisan yang diterima tersebut perlu dijaga dan dikelola dengan baik untuk generasi anak-cucu mereka.

Pada tahapan pemanenan ini, terdapat ritual yang dipraktkan secara turun-temurun, yaitu

1. Ritual penggosokan minyak kelapa sebelum penebangan dan pemanenan kulit kayu dan

2. Ritual persemabahan sesajian berupa sepiring sirih, pinang, tembakau dan rokok yang diletakkan dibawah pohon masohi

Adat istiadat masyakat lokal meyakini bahwa kehadiran masohi diibaratkan seperti roh manusia dari leluhur sehingga perlu diberi makan lewat sesajian sirih, pinang, kapur, tembakau negeri yang diletakkan dengan sebuah wadah yang terbuat dari daun pandan/piring dengan alas batu pada bawah pohon sebagai tanda penghormatan. Bersamaan dengan kegiatan ritual tersebut juga dilakukan pembersihan tegakan bawah pohon dari rumput dan tumbuhan lain di sekitarnya.

Proses pemanenan pohon masohi didahului dengan ritual baca doa atau mantra singkat dengan menggunakan kapas yang sudah direndam dengan minyak kelapa pada wadah yang telah disiapkan. Selanjutnya minyak yang telah dibacakan doa tersebut digosokkan pada batang pohon secara melingkar, ke arah atas dan ke bawah batang pohon.

Demikian pula alat kerja (parang/ kampak) dan telapak tangan orang yang 
turut di dalam proses pemanenan digosok menggunakan minyak yang sama. Ritual dipimpin oleh orang yang sudah dipercaya di dalam keluarga (Tetua Adat atau anak pertama atau yang diwakilkan). Ritual ini dilakukan dengan maksud agar pada saat penebangan tidak akan dijumpai adanya hambatan seperti orang terasa kaku/lumpuh pada tangan atau kaki (Gambar 7).
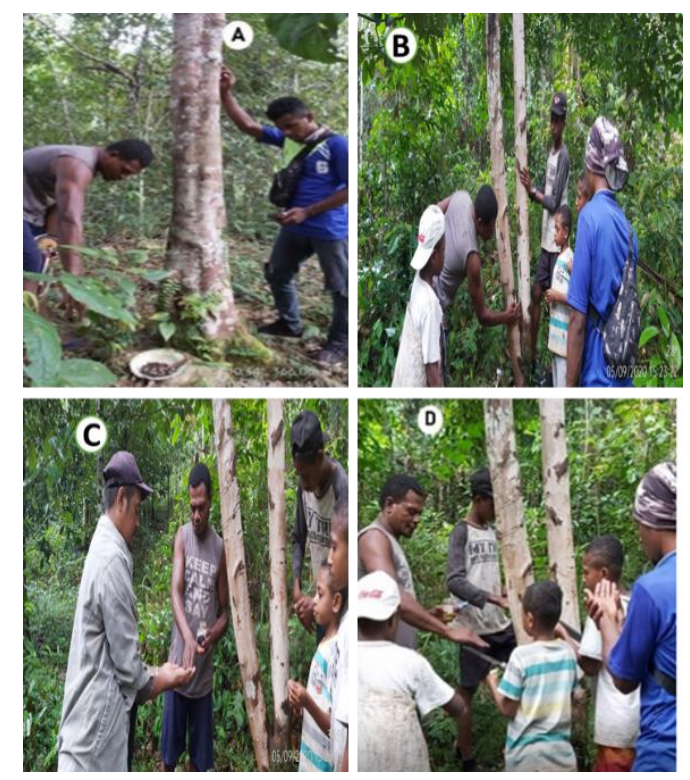

Gambar 7. Ritual dalam pemanenan masohi secara tradisional. A. Ritual sesajian sepiring sirih, pinang dan tembakau atau rokok yang diletakkan di bawah pohon masohi dan BD. Ritual menggosok pohon, tangan pekerja dan peralatan dengan minyak kelapa sebelum dilakukan pemanenan kulit kayu.

Syarat lingkar pohon yang dipanen adalah $\pm 15 \mathrm{~cm}$ (Luanmansar, 2010) dengan proses persentase pemanenan dapat dilihat pada Gambar 8. Sistem penebangan tersebut setelah dipegang oleh generasi muda sudah mulai berubah seiring dengan pengetahuan, teknologi pemanenan dan sosialisasi yang diberikan oleh UPT Dinas Kementerian
Lingkungan Hidup dan Kehutanan. Hal ini ditunjukkn dari beberapa lahan mereka yang hanya diambil kulit masohinya saja tanpa dilakukan penebangan.

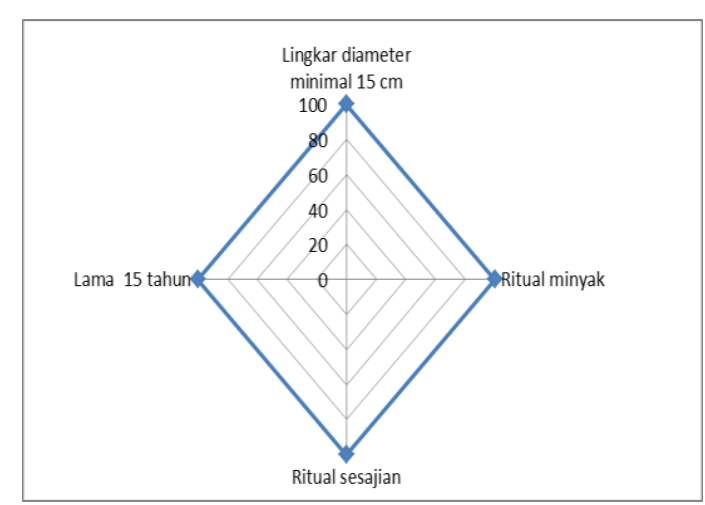

Gambar 8. Persentase pemanenan

\section{Praktek Pengeringan}

Pemanenan kulit masohi dilakukan apabila ada pembeli untuk menghindari kesulitan dalam penjualan. Setelah pemanenan, tahapan berikutnya pengolahan kulit kayu.

Pemilahan kulit kayu dilakukan dengan memisahkan antara lembaran/gulungan kulit kayu dengan serpihan besar dan serpihan kecil secara terpisah. Selanjutnya kulit kayu masohi hasil dari pemilahan, dilakukan penjemuran. Terdapat dua macam metode penjemuran yaitu menggunakan metode penjemuran matahari dan metode pengasapan. Metode pengasapan dilakukan hanya bila cuaca kurang baik dan ini dilakukan untuk mencegah terjadi pertumbuhan jamur.

Metode pengasapan bukan pilihan yang baik bagi petani masohi karena kulit kayu masohi yang dihasilkan berkualitas kurang baik dengan penampakan yang lebih gelap akibat pengasapan serta membutuhakan waktu lebih lama \pm 1 bulan. Pengeringan utama tetap mengandalkan panas matahari selama 2-3 hari yang dilakukan baik di pondok kebun ataupun di rumah petani masohi (Gambar 9). 
Kulit kayu masohi yang telah kering ditandai terasa rapuh saat dipatahkan. Selanjutnya kulit kayu masohi dimasukkan kedalam karung, dan mulut karung dijahit atau diikat. Kulit kayu masohi yang telah melalui proses pengeringan ini selanjutnya siap untuk dijual kepada pedagang pengumpul atau pedagang pemegang ijin.

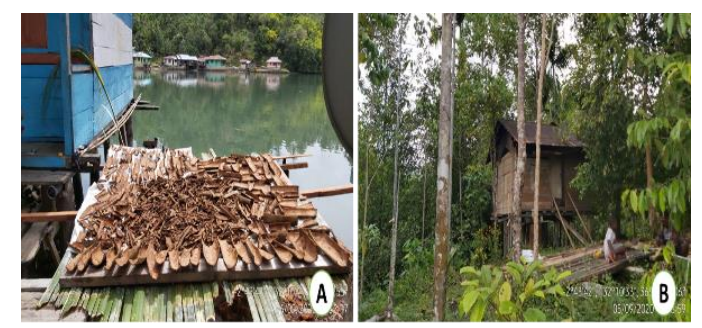

Gambar 9. Teknik pengeringan kulit Masohi dengan panas matahari (A) dan pengasapan (B)

Proses keseluruhan tahapan pengolahan kulit masohi dapat dilihat pada Gambar 10.

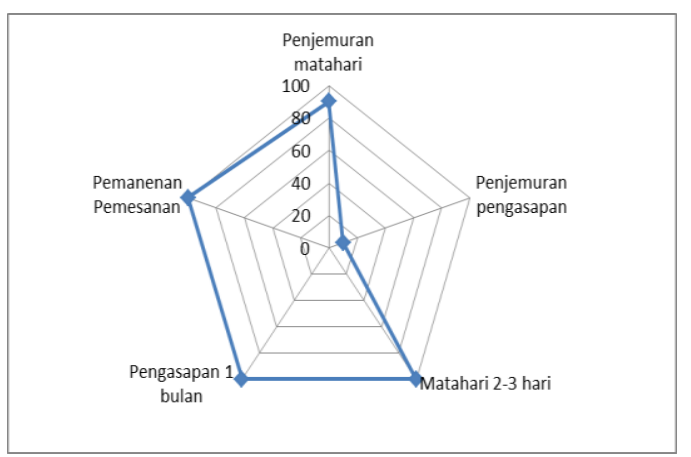

Gambar 10. Persentase pengeringan

Pengelolaan masohi berdasarkan pengetahuan lokal dari masyarakat adat terkait dari sejarah lahan dan tanaman, teknik budidaya, pemanenan dan praktek pengeringan memiliki kategori masingmasing cukup, sangat baik, sangat baik dan sangat baik. Hal ini menunjukkan bahwa dalam setiap proses pengelolaan masohi sudah mempertimbangkan pengetahuan lokal yang berbasis pengelolaan masohi secara berkelanjutan dengan sistem budidaya berbasis masyarakat adat.

Hal ini disebabkan ketersediaan masohi di hutan alam yang sudah sangat sulit ditemukan sehingga praktek budidaya ini patut dilestarikan dengan tetap menerima beberapa input untuk perbaikan di masa mendatang.

\section{KESIMPULAN}

1. Tidak dijumpainya anakan masohi di hutan alam milik komunal masyarakat adat Distrik Teluk Patipi.

2. Teknik budidaya perlu dikembangkan untuk pelestarian masohi dengan adaptasi terhadap perubahan iklim.

3. Adat istiadat pengelolaan masohi masih terjaga dengan baik.

4. Pengeringan kulit masohi diperlukan alat pengering selain menggunakan pengeringan dengan matahari.

\section{SARAN}

Teknologi biopori, pemanenan, dan alat pengering portable serta peningkatan sosialisasi plus industri hilirisasi berupa minyak masohi diperlukan untuk meningkatkan harga jual dan kesejatehraan petani masohi.

\section{DAFTAR PUSTAKA}

Baharuddin, dan I. Taskirawati. (2009). Hasil Hutan Bukan Kayu. Makasar.Universitas Hasanuddin.

BP2I. (2014). HHBK, Potensi Pemberdayaan Masyarakat Sekitar Hutan. Persentasi, Bogor, 3 Juli 2014.

Cohen, et al. (2007). Metode Penelitian dalam Pendidikan. New York. Routledge. 657 Hal.

Dahliati, A., Nugroho, TT., Nurulita, Y., dan Helianty, S. (2019). Penerapan Teknologi Biopori dalam Pencegahan Banjir Kekeringan yang sekaligus Pembuatan 
Kompos di Keluarahan Delima Kecamatan Tampan Pakanbaru. Hastanti B. W., Relawan K, dan Julanda N. (2016). Strategi Pengembangan Hasil Hutan Bukan Kayu (HHBK) MASOHI (Cryptocarya masohia (Oken) Kosterm.) di Teluk Bintuni, Papaua Barat dengan Analisis SWOT.

Hutapea FJ., Kuswandi R., dan Asmoro JP. (2020). Potensi dan Sebaran Masohi (Cryptocarya massoy) di Kabupaten Teluk Bintuni dan Kabupaten Kaimana. Jurnal Faloak 4(1):57-70

Luanmasar DR. (2010). Hubungan diameter Pohon terhadap Produksi Kulit Masohi (Cryptocarya masohi) pada Hutan Lindung Tunggaromi, Kabupaten Kaimana. Universitas Papua (Skripsi)

Nugroho JD., Wanma JF., Susanti CME., Husodo SB., dan Mawikere NL. (2019). Penurunan Stok Tegakan Alami Masohi [Cryptocarya massoy (Oken) Kosterm] di Kabupaten Nabire. Igya Ser Hanjop 1(1):11-18.

Salaka F. J., Bramasto N., Dodik R. N. (2010). Strategi Kebijakan Pemasaran Hasil Hitan Bukan Kayu di Kabupaten Seram Bagian Barat, Provinsi Maluku.

Sudarmalik, Rochmayanto Y, Purnomo. (2006). Peranan beberapa hasil hutan bukan kayu (HHBK) di Riau dan Sumatera Barat. Prosiding Seminar Hasil Litbang Hasil Hutan 2006: 199-219.

Ulfah, M., Dewi, ERS., Rahayu, P., dan Dwei, RS. (2016). Pengelolaan LRB sebagai Upaya Meningkatkan Daya Resap Air pada Tanah. Jurnal E-Dimas, 7 (1): 27-37.

Westphal E and Jansen P.C.M.(editor). (1989). Plant Resources of SouthEast Asia: A selection. Pudoc Wageningen
Yeny, I., Narendra, B. H., \& Nuroniah, H. S. (2018). Potensi pengembangan masoyi (Cryptocarya massoy (Oken) Kosterm) di wilayah UPTD KPH Unit V Boalemo berdasarkan kesiapan masyarakat dan tingkat kesiapan lahan. Jurnal Penelitian. Hutan Tanaman, 15(2):125-145. 